\title{
Managing water in rainfed agriculture-The need for a paradigm shift
}

\author{
Johan Rockström ${ }^{\mathrm{a}, \mathrm{b}, *}$, Louise Karlberg ${ }^{\mathrm{a}, \mathrm{b}}$, Suhas P. Wani ${ }^{\mathrm{c}}$, Jennie Barron ${ }^{\mathrm{a}, \mathrm{b}}$, Nuhu Hatibu ${ }^{\mathrm{d}}$, \\ Theib Oweis ${ }^{\mathrm{e}}$, Adriana Bruggeman ${ }^{\mathrm{e}}$, Jalali Farahani ${ }^{\mathrm{e}}$, Zhu Qiang ${ }^{\mathrm{f}}$ \\ a Stockholm Environment Institute (SEI), Kräftriket 2B, Stockholm 106 91, Sweden \\ ${ }^{\mathrm{b}}$ Stockholm Resilience Centre, Stockholm University, Stockholm 106 91, Sweden \\ ${ }^{\mathrm{c}}$ International Crops Research Institute for Semi-Arid Tropics (ICRISAT), Patancheru 502324, India \\ ' $S W M N E T$, ICRISAT, Nairobi, Kenya \\ e ICARDA, Aleppo, Syria \\ ${ }^{\mathrm{f}}$ Gansu Research Institute for Water Conservancy, Lanzhou 730000, China
}

\section{A R T I C L E I N F O}

\section{Article history:}

Available online 6 November 2009

\section{Keywords:}

Catchment management

Integrated water resources management (IWRM)

Water productivity

\begin{abstract}
A B S T R A C T
Rainfed agriculture plays and will continue to play a dominant role in providing food and livelihoods for an increasing world population. We describe the world's semi-arid and dry sub-humid savannah and steppe regions as global hotspots, in terms of water related constraints to food production, high prevalence of malnourishment and poverty, and rapidly increasing food demands. We argue that major water investments in agriculture are required. In these regions yield gaps are large, not due to lack of water per se, but rather due to inefficient management of water, soils, and crops. An assessment of management options indicates that knowledge exists regarding technologies, management systems, and planning methods. A key strategy is to minimise risk for dry spell induced crop failures, which requires an emphasis on water harvesting systems for supplemental irrigation. Large-scale adoption of water harvesting systems will require a paradigm shift in Integrated Water Resource Management (IWRM), in which rainfall is regarded as the entry point for the governance of freshwater, thus incorporating green water resources (sustaining rainfed agriculture and terrestrial ecosystems) and blue water resources (local runoff). The divide between rainfed and irrigated agriculture needs to be reconsidered in favor of a governance, investment, and management paradigm, which considers all water options in agricultural systems. A new focus is needed on the meso-catchment scale, as opposed to the current focus of IWRM on the basin level and the primary focus of agricultural improvements on the farmer's field. We argue that the catchment scale offers the best opportunities for water investments to build resilience in smallscale agricultural systems and to address trade-offs between water for food and other ecosystem functions and services.
\end{abstract}

(c) 2009 Published by Elsevier B.V.

\section{Need for investments in water management to upgrade rainfed agriculture}

Agriculture plays a key role in economic development (World Bank, 2005) and poverty reduction (Irz and Roe, 2000). In sub-Saharan Africa 35\% of GDP comes from the agricultural sector, which also employs about $70 \%$ of the population (World Bank, 2000). Growth in the agricultural sector is essential for achieving the Millennium Development Goals (MDGs) of eradicating hunger and poverty. The required growth corresponds to no less than a new green revolution (Conway and Toenniessen, 1999;

\footnotetext{
* Corresponding author at: Stockholm Environment Institute (SEI), Kräftriket 2B, Stockholm 106 91, Sweden.

E-mail addresses: johan.rockstrom@sei.se (J. Rockström), n.hatibu@cgiar.org (N. Hatibu), t.oweis@cgiar.org (T. Oweis), qzhu@zgb.com.cn (Z. Qiang).
}

Falkenmark and Rockström, 2004), with a doubling of food production over the coming 20-30 years, particularly in subSaharan Africa and parts of South and East Asia, where malnourishment and growth of food demand are highest (UN Millennium Project, 2005).

No economic sector consumes as much freshwater as agriculture, with an estimated $1300 \mathrm{~m}^{3} \mathrm{cap}^{-1}$ year $^{-1}$ required to produce an adequate diet (Falkenmark and Rockström, 2004). Scenario analysis shows that approximately $7100 \mathrm{~km}^{3}$ year $^{-1}$ are consumed globally to produce food, of which $5500 \mathrm{~km}^{3}$ year $^{-1}$ are used in rainfed agriculture and $1600 \mathrm{~km}^{3}$ year ${ }^{-1}$ in irrigated agriculture (de Fraiture et al., 2007; CA, 2007). The analysis also describes large increases in the amount of water needed to produce food by 2050 , ranging from 8500 to $11,000 \mathrm{~km}^{3}$ year $^{-1}$, depending on assumptions regarding improvements in rainfed and irrigated agricultural systems.

Climate change may further undermine attempts to mobilize the necessary water resources, due to observed reductions in 


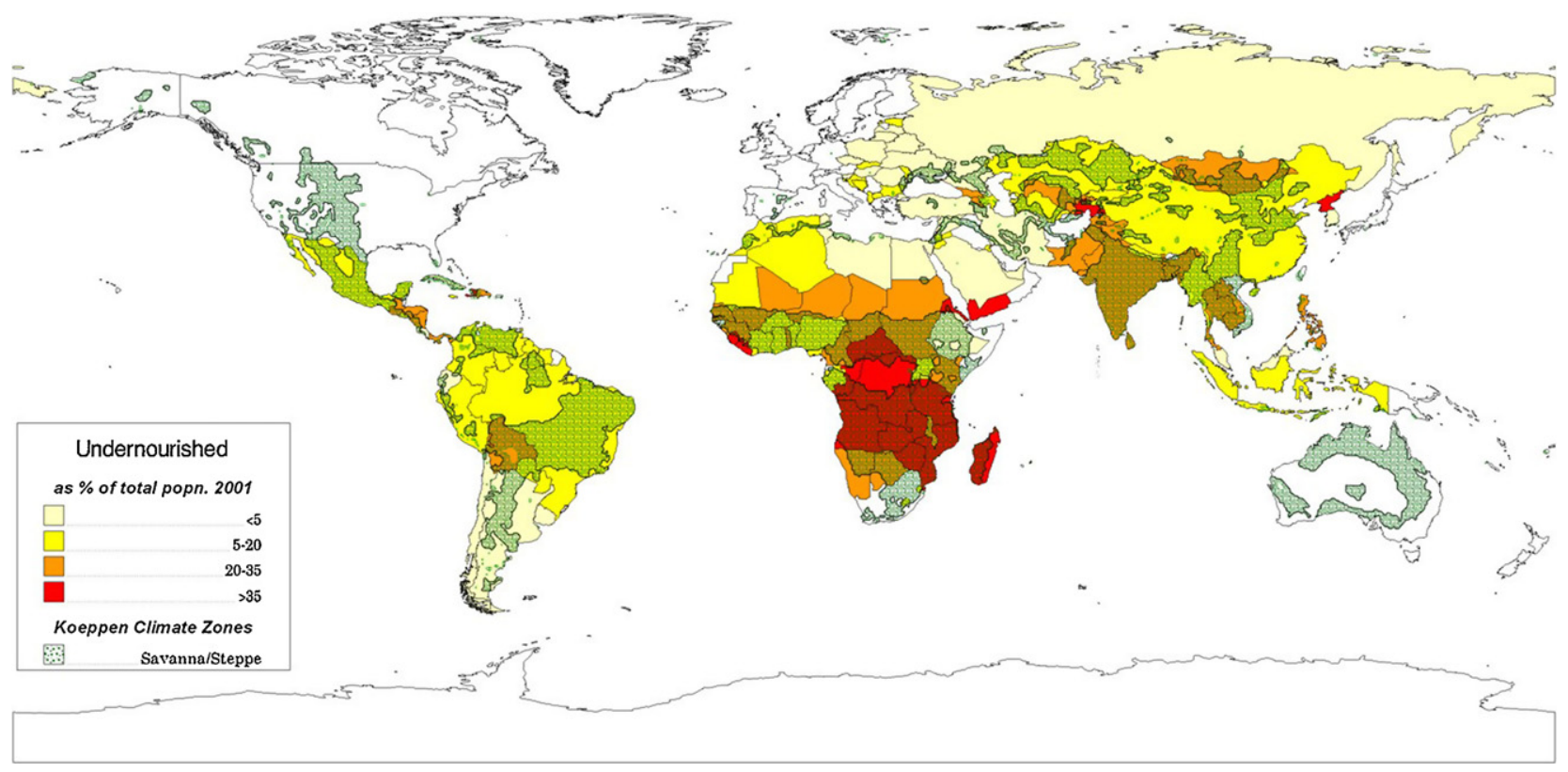

Fig. 1. Number of undernourished as a share of the total population, in relation to the location of semi-arid and dry sub-humid regions (UNStat, 2005).

rainfall in the lower tropical latitudes (Zhang et al., 2007). Some experts are predicting further declines in rainfall and amplification of extreme events (IPCC, 2007). Current irrigation water withdrawals already cause stress in many of the world's major river basins (Molle et al., 2007). The world likely is facing a water crisis with little room for further expansion of large-scale irrigation. This accentuates the need for water management in rainfed agriculture; not only to secure the water required for food production, but also to build resilience for coping with future water related risks and uncertainties. Thus, the current state-of-affairs and future scenarios all point to the same outcome: rainfed agriculture will continue to play a crucial and dominant role in providing food and livelihoods for an increasing world population.

Rainfed crop production, which uses infiltrated rainfall that forms soil moisture in the root zone (the so-called green water resource), accounts for most of the crop water consumption in agriculture. The Comprehensive Assessment of Water Management in Agriculture (CA, 2007) describes a large, untapped potential for upgrading rainfed agriculture and calls for increased water investments in the sector. In this paper we analyze how and where these investments should occur, with the goal of significantly upgrading rainfed agriculture in a sustainable manner.

\section{Zooming in on global hotspots}

Many farming systems have adapted to hydro-climatic gradients. Examples include pastoral systems in arid environments, agro-pastoral systems in the drier semi-arid zone, and sedentary, multiple cropping systems in the savannah systems and humid agroecosystems. The challenge of upgrading rainfed agriculture through improved water management is concentrated in the world's savannah and steppe regions. These cover the semiarid and dry sub-humid climate regions where rainfed agriculture is the dominant source of livelihood and where water availability limits crop production (SEI, 2005). Falkenmark (1986) shows a correlation between hydro-climatic constraints and poverty. Countries with a high prevalence of malnutrition and a many poor people depending on farming, commonly are situated in the semi-arid and dry sub-humid (savannah and steppe) climatic regions (CA, 2007) (Fig. 1). We consider these regions to be global hotspots.

\section{Large untapped potential-exploiting the yield gap and apparent hydro-climatic constraints}

From a global perspective, agricultural productivity is lower in rainfed areas than in irrigated farming systems. In developing countries, rainfed grain yields average $1.5 \mathrm{t} \mathrm{ha}^{-1}$, compared with $3.1 \mathrm{tha}^{-1}$ in irrigated agriculture (Rosegrant et al., 2002). In temperate commercial agriculture, rainfed yields of major grain crops often exceed $5 \mathrm{tha}^{-1}$ (FAOSTAT, 2005). Similarly, in tropical regions, yields in commercial rainfed agricultural systems often exceed 5-6 tha ${ }^{-1}$. These observations suggest that the apparent biophysical constraints causing low yields in rainfed farming systems in tropical developing countries might be overcome with appropriate management (Rockström and Falkenmark, 2000; Wani et al., 2003a,b).

In Patancheru, India, the yield of a sorghum/pigeonpea intercropping system increased from $1.1 \mathrm{tha}^{-1}$ with standard practices to $5.1 \mathrm{t} \mathrm{ha}^{-1}$ with improved management (Fig. 2). In the dry sub-humid and the semi-arid zones, where farming systems have experienced the lowest yields and the weakest yield improvements during the past decades (FAOSTAT, 2005), dry spell mitigation is a common water management practice for

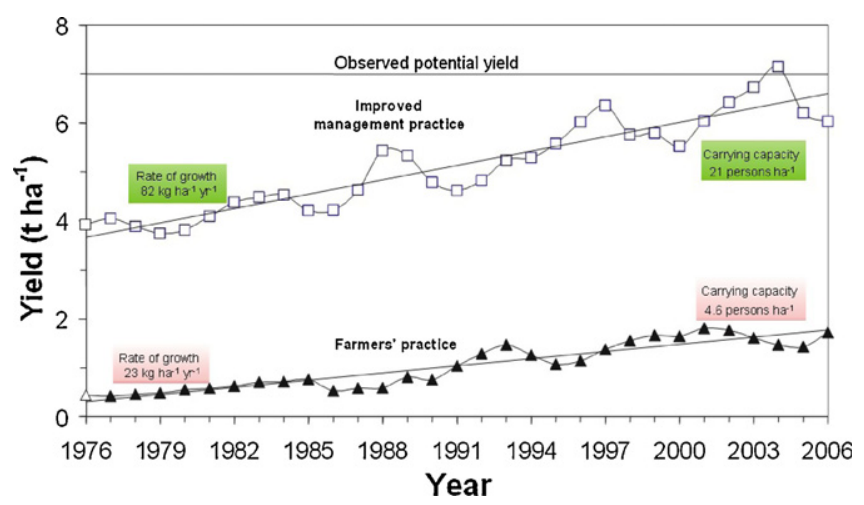

Fig. 2. Long-term crop yields under rainfed conditions. (a) Sorghum grown with farmers' management; and (b) sorghum/pigeonpea grown with improved soil water, nutrient and crop management. ICRISAT, Patancheru, India.Source: Wani et al. (2003a). 


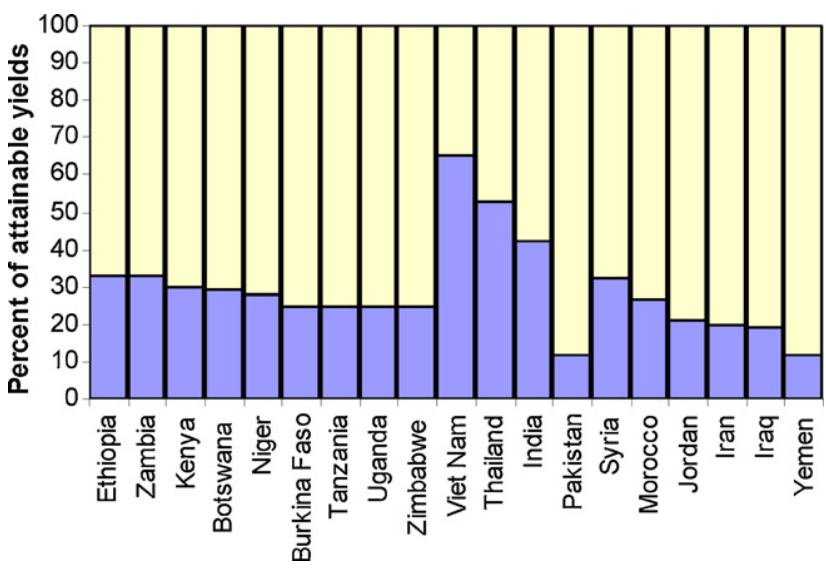

Fig. 3. Yield gaps for major grains in rainfed agriculture, for selected African, Asian and Middle East countries. Actual yields compared to attainable yields.

minimizing the risk of crop failure due to drought. The large gaps between actual and attainable yields in rainfed agriculture in many regions of the world (Fig. 3) suggest a large untapped potential for yield increases.

In the semi-arid and dry sub-humid zone, it is not the amount of rainfall that is the limiting factor of production (Fig. 4) (Klaij and Vachaud, 1992; Agarwal, 2000; Hatibu et al., 2003; Wani et al., 2003b). Rather, it is the extreme variability of rainfall, with high rainfall intensities, few rain events, and poor spatial and temporal distribution of rainfall. By contrast, in the arid zone, crop water needs often exceed total rainfall, causing absolute water scarcity.

In semi-arid and sub-humid agroecosystems, dry spells (short periods of drought during critical growth stages) occur in almost every rainy season (Table 1) (Barron et al., 2003). By contrast, meteorological droughts occur on average once or twice every decade. Frequencies of both meteorological droughts and dry spells are predicted to increase with climate change (IPCC, 2007). While dry spells can be bridged through investments in appropriate water management techniques, crop yields cannot be sustained during a meteorological drought, and different coping mechanisms are required.

Farming systems often suffer from agricultural droughts and dry spells caused by management induced water scarcity (Rockström et al., 2007). On-farm water balance analysis indicates that in savannah farming systems in sub-Saharan Africa less than $30 \%$ of rainfall is used as productive transpiration by crops. On severely degraded land this proportion can be as small as 5\% (Rockström, 2003). Thus, crop failures commonly blamed on "drought," might be prevented in many cases through better farm-level water management.

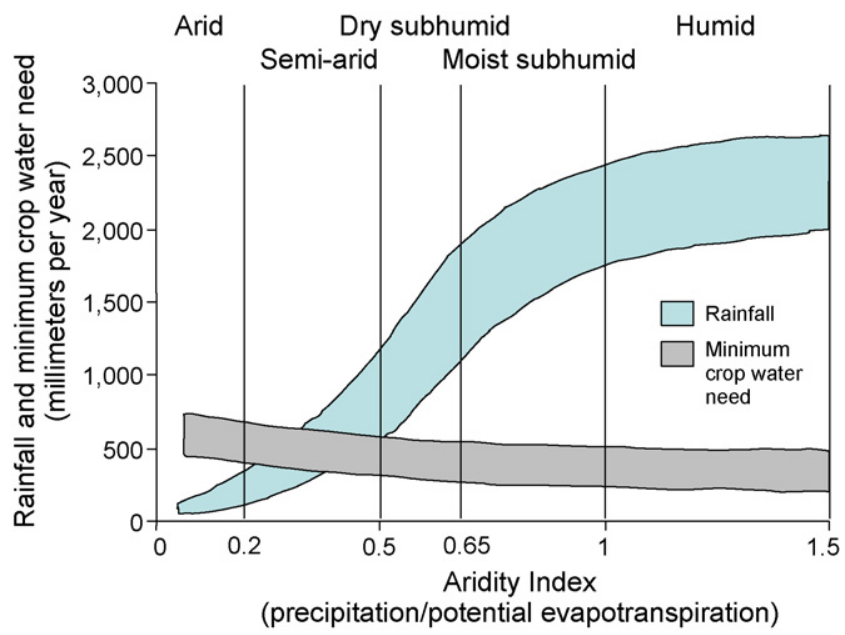

Fig. 4. Range of rainfall variability across hydro-climatic zones from arid to humid agroecosystems. The ecosystem gradient is shown as the aridity index (ratio of annual precipitation to annual potential evapotranspiration). The range in total rainfall is expressed as plus or minus one standard deviation. Minimum crop water needs from Doorenbos and Pruitt (1992) and adjusted for aridity index.

Many non-water factors also limit production in rainfed agriculture. Commonly, nutrient poor soils are the limiting factor to growth (Stoorvogel and Smaling, 1990) even in water scarce regions. Production is also limited by labour shortages, insecure land ownership, inadequate access to capital for investments, and limited skills and abilities. As a result, actual production often falls short of potential output. Rainfed agriculture in regions characterized by erratic rainfall is subject to large inherent water related risks, which make farmers less likely to invest in nutrients and other production enhancing inputs. If these risks can be lowered through investments in water management techniques to bridge dry spells, farmer attitudes regarding agricultural investments might also change. In rainfed areas, rainfall is the most prominent random parameter beyond farmers' control. Hence rainfall is both a critical input and a primary source of risk and uncertainty regarding production outcomes.

Previous investments in research on dry land agriculture in the savannah zone have shown mixed results in terms of improvements in agricultural productivity (Seckler and Amarasinghe, 2004). This may be due to the lack of focus on water resource management in rainfed areas (CA, 2007). Much of the focus in recent decades has been on erosion control through soil conservation measures, soil fertility, pest control, and crop management. Water has primarily been an issue of in-situ moisture management; i.e., maximizing rainfall infiltration through moisture conservation techniques, rather than managing water

Table 1

Types of water stress and underlying causes in semi-arid and dry sub-humid tropical environments.

\begin{tabular}{|c|c|c|}
\hline & Dry spell & Drought \\
\hline \multicolumn{3}{|l|}{ Meteorological } \\
\hline Frequency & Two out of three years & One out of ten years \\
\hline Impact & Yield reduction & Complete crop failure \\
\hline Cause & $\begin{array}{l}\text { Rainfall deficit of two- to five-week } \\
\text { periods during crop growth }\end{array}$ & Seasonal rainfall below minimum seasonal plant water requirement \\
\hline \multicolumn{3}{|l|}{ Agricultural } \\
\hline Frequency & More than two out of three years & One out of ten years \\
\hline Impact & Yield reduction or complete crop failure & Complete crop failure \\
\hline Cause & $\begin{array}{l}\text { Low plant water availability and poor } \\
\text { plant water uptake capacity }\end{array}$ & $\begin{array}{l}\text { Poor rainfall partitioning, leading to seasonal soil moisture deficit for } \\
\text { producing harvest (where poor partitioning refers to a high proportion } \\
\text { of runoff and non-productive evaporation relative to oil water } \\
\text { infiltration at the surface) }\end{array}$ \\
\hline
\end{tabular}


Table 2

Rainwater management strategies and corresponding management options to improve yields and water productivity.

\begin{tabular}{|c|c|c|c|}
\hline \multicolumn{2}{|c|}{ Rainwater management strategy } & \multirow{2}{*}{$\begin{array}{l}\text { Purpose } \\
\text { Mitigate dry spells, protect springs, recharge } \\
\text { groundwater, enable off-season irrigation, } \\
\text { permit multiple uses of water }\end{array}$} & \multirow{2}{*}{$\begin{array}{l}\text { Management options } \\
\text { Surface microdams, subsurface tanks, farm ponds, } \\
\text { percolation dams and tanks, diversion and } \\
\text { recharging structures }\end{array}$} \\
\hline $\begin{array}{l}\text { Increase plant water } \\
\text { availability }\end{array}$ & $\begin{array}{l}\text { External water harvesting } \\
\text { systems }\end{array}$ & & \\
\hline & $\begin{array}{l}\text { In-situ water harvesting systems, } \\
\text { soil and water conservation }\end{array}$ & $\begin{array}{l}\text { Concentrate rainfall through runoff to } \\
\text { cropped area or other use }\end{array}$ & $\begin{array}{l}\text { Bunds, ridges, broad-beds and furrows, } \\
\text { microbasins, runoff strips }\end{array}$ \\
\hline & & Maximize rainfall infiltration & $\begin{array}{l}\text { Terracing, contour cultivation, conservation } \\
\text { agriculture, dead furrows, staggered trenches }\end{array}$ \\
\hline & Evaporation management & Reduce non-productive evaporation & $\begin{array}{l}\text { Dry planting, mulching, conservation agriculture, } \\
\text { intercropping, windbreaks, agroforestry, early plant } \\
\text { vigor, vegetative bunds }\end{array}$ \\
\hline $\begin{array}{l}\text { Increase plant water } \\
\text { uptake capacity }\end{array}$ & $\begin{array}{l}\text { Integrated soil, crop and } \\
\text { water management }\end{array}$ & $\begin{array}{l}\text { Increase proportion of water balance } \\
\text { flowing as productive transpiration }\end{array}$ & $\begin{array}{l}\text { Conservation agriculture, dry planting (early), } \\
\text { improved crop varieties, optimum crop geometry, } \\
\text { soil fertility management, optimum crop rotation, } \\
\text { intercropping, pest control, organic matter management }\end{array}$ \\
\hline
\end{tabular}

resources to bridge periods of scarcity. A key reason for this mismatch might be the lack of policies governing water management in rainfed agriculture (Hatibu et al., 1999). While water governing institutions traditionally have addressed issues of delivering water to households, industries and irrigation schemes, institutions governing agriculture (e.g., Ministries for Agriculture) have focused on "dry" issues, such as soil management strategies for erosion control. Some researchers and public officials are beginning to focus more closely on water management in rainfed agriculture. Examples include watershed development programmes in India (India, 2005) and agricultural policies implemented in Tanzania (Tanzania Ministry of Agriculture and Food Security, 2003).

\section{Potential for new investments in water management techniques}

There are two broad strategies for increasing yields in rainfed agriculture when water availability in the root zone constrains crop growth: (1) capturing more water and allowing it to infiltrate into the root zone; and (2) using the available water more efficiently (increasing water productivity) by increasing the plant water uptake capacity and/or reducing non-productive soil evaporation. There is a wide spectrum of integrated land and water management options for use in achieving these aims (Table 2). While most techniques, such as external water harvesting systems, focus on capturing more water, several focus on increasing water productivity directly; e.g., drip-irrigation and mulching. Management approaches aimed at capturing more water often lead also to higher water productivity, as denser crop canopies shadow the soil and thus reduce soil evaporation (Rockström, 2003).

Water harvesting pertains to any practice that collects runoff for productive purposes (Siegert, 1994). A distinction is often made between in-situ water harvesting; i.e., the capture of local rainfall on farmland, and ex-situ water harvesting; i.e., the capture of rainfall that falls outside the farmland (Oweis and Hachum, 2001).

Supplemental irrigation systems are ex-situ water harvesting systems, providing water during periods when rainfall is insufficient to provide essential soil moisture to secure a harvest. In such systems, water scheduling is not designed to meet the full plant water requirements. Instead, the critical importance of the systems is their capacity to bridge dry spells and, consequently, to reduce risks in rainfed agriculture. According to Oweis (1997), supplemental irrigation of $50-200 \mathrm{~mm}$ can bridge critical dry spells and stabilize yields in arid to dry sub-humid regions. The potential yield increase in supplemental irrigation varies with rainfall. An example from Syria illustrates that improvements in yields can be more than $400 \%$ in arid regions (Oweis, 1997).

Several studies indicate that supplemental irrigation systems are affordable for small-scale farmers (Fan et al., 2000; Fox et al., 2005). However, policy frameworks, institutional structures, and human capacities similar to those for full irrigation infrastructure are required to successfully apply supplemental irrigation in rainfed agriculture.

Rainfed agriculture has traditionally been managed at the fieldscale. Supplemental irrigation systems, with storage capacities generally in the range of $100-10,000 \mathrm{~m}^{3}$, even though small in comparison to irrigation storage, require planning and management at the catchment scale, as capturing local runoff may impact other water users and ecosystems. Legal frameworks and water rights pertaining to the collection of local surface runoff are required, as are human capacities for planning, constructing, and maintaining storage systems for supplemental irrigation. Moreover, farmers must be able to take responsibility for the operation and management of the systems. Supplemental irrigation systems also can be used in small vegetable gardens during dry seasons to produce fully irrigated cash crops. Supplemental irrigation is a key strategy, still underused, for unlocking rainfed yield potential and water productivity.

Soil and water conservation, or in-situ water harvesting, has been the focus of most of the investment in water management in rainfed agriculture during the past 50 years. Since in-situ water harvesting can be applied on any piece of land and is affordable to most smallholder farmers (e.g., Wani et al., 2003b; Sreedevi et al., 2004), these management systems may already be in place prior to investing in ex-situ water harvesting options. Field observations in semi-arid regions of Kenya indicate that the farmers who have adopted or are willing to adopt ex-situ water harvesting systems, often also have well advanced practices of in-situ water harvesting systems (Mwangi Hai, pers. comm.) ${ }^{1}$.

Conservation agriculture ${ }^{2}$ is a term describing in-situ water harvesting techniques that include a range of non-inversion

\footnotetext{
${ }^{1}$ World Agroforestry Centre (ICRAF), United Nations Avenue, Gigiri, PO Box 30677-00100 GPO, Nairobi, Kenya. Telephone: +254 20722 4000, http:// www.worldagroforestrycentre.org.

2 Here conservation agriculture is understood as the equivalent to conservation farming and conservation tillage, i.e., non-inversion tillage systems with mulch. The strict definition of a conservation agriculture system stipulates at least $30 \%$ soil cover with mulch throughout the year, which is an important and desirable aim, even though difficult for farmers in savannah regions to attain due to biomass deficiencies.
} 


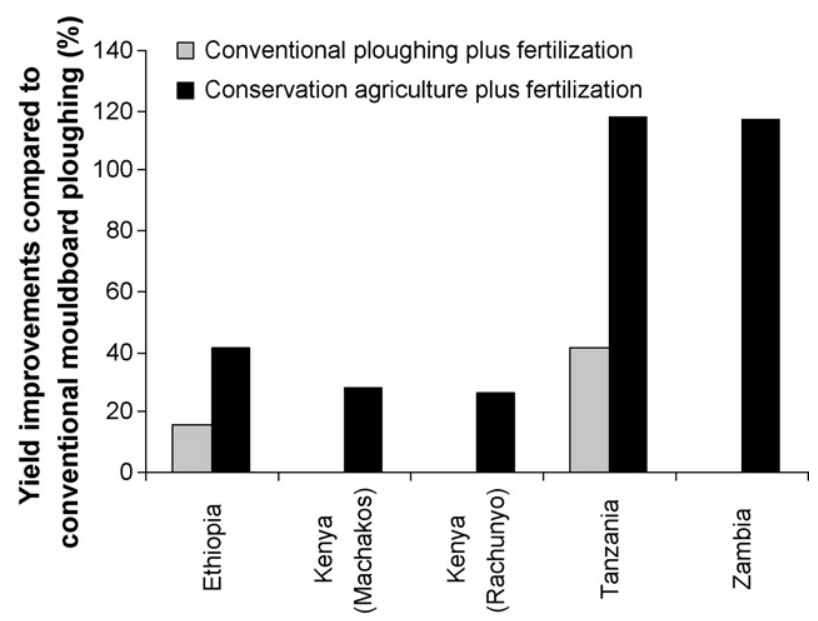

Fig. 5. Maize yield improvements through conservation agriculture in on-farm trials in East Africa.Data from Rockström et al. (2009a).

cultivation systems; i.e., those that involve minimum disturbance of the soil by machines. In most cases, plowing is replaced with a technique such as ripping the soil where seeds will be planted, deep ripping the soil to break up hard or compacted layers (subsoiling), or using direct planting techniques (no-till). Any of these techniques, when used in combination with mulching to build organic matter and improve soil structure, is considered to be conservation agriculture.

Some form of conservation agriculture is practiced on $40 \%$ of rainfed farmland in the United States and has generated an agricultural revolution in several countries in Latin America (Derpsch, 1998, 2005; Landers et al., 2001). Moreover, conservation agriculture is common among small-scale farmers on the Indo-Gangetic plains (Hobbs and Gupta, 2002). Examples from sub-Saharan Africa show that converting from plowing to conservation agriculture results in yield improvements ranging between $20 \%$ and $120 \%$, with water productivity improving from $10 \%$ to $40 \%$ (Fig. 5) (Rockström et al., 2009b). Other advantages of non-inversion tillage systems include a savings in labour related to plowing. Potential disadvantages include higher costs of pest and weed control, the cost of acquiring new management skills, and investments in new planting equipment. Conservation agriculture is relatively cheap to implement, however, and it can be practiced on all soils and does not require water storage devices. As a result, the approach is quite important for upgrading rainfed agriculture, which often is constrained by lack of investment capital.
In semi-arid areas up to $50 \%$ of the rainfall is lost from the fields as non-productive soil evaporation (Rockström, 2003). Converting some of that water to productive transpiration through evaporation management will increase water productivity in the arid, semi-arid and dry sub-humid regions. Options to reduce soil evaporation include dry planting, conservation agriculture, and mulching. Higher water productivity is achieved also by improving crop yields. When yields are low (between 1 and $2 \mathrm{tha}^{-1}$ ), even small improvements in yield will generate large gains in water productivity (Fig. 6). This non-linear relationship between water productivity and yield is due to the shading of the soil when the crop canopy becomes denser with higher yield, thus changing the ratio between productive transpiration and non-productive evaporation (Rockström, 2003). Hence efforts to improve crop yields are beneficial from both water saving and income enhancing perspectives.

\section{Balancing water for humans and nature}

Every increase in water use in agriculture will inevitably affect water availability for other uses, such as drinking water supply and ecosystem enhancement. Upgrading rainfed agriculture may result in water trade-offs with downstream users and ecosystems (Calder, 1999), particularly in closed and closing basins, where more water is used than is renewably available during some portion of the year (Molden et al., 2001; Molle, 2003). In other cases the downstream impacts on stream flow from small-scale water storage systems have been limited, even if implemented widely (Evenari et al., 1971; Schreider et al., 2002; Sreedevi et al., 2006).

Because evaporation management (i.e., shifting non-beneficial soil evaporation to beneficial transpiration) does not directly impact local runoff, this strategy creates a large opportunity for improving yields from rainfed agriculture without affecting downstream water users and ecosystems. By contrast, water harvesting strategies that decrease runoff can have negative impacts downstream. However, capturing runoff close to the source, as is the case for water harvesting systems, may result in lower consumptive water losses by reducing the transmission losses encountered when locally generated surface runoff flows to downstream rivers. However, this theory has not yet been verified. Capturing runoff may also reduce land degradation from water erosion, improve water quality, and retain water at higher altitudes, where it can be used to extend gravity-fed supplemental irrigation (Bewket and Sterk, 2005). In some cases the conversion of natural ecosystems into agriculture has reduced evapotranspiration (Gerten et al., 2005), and forestry has been shown to reduce runoff in South Africa (Jewitt et al., 2004). Expanding the

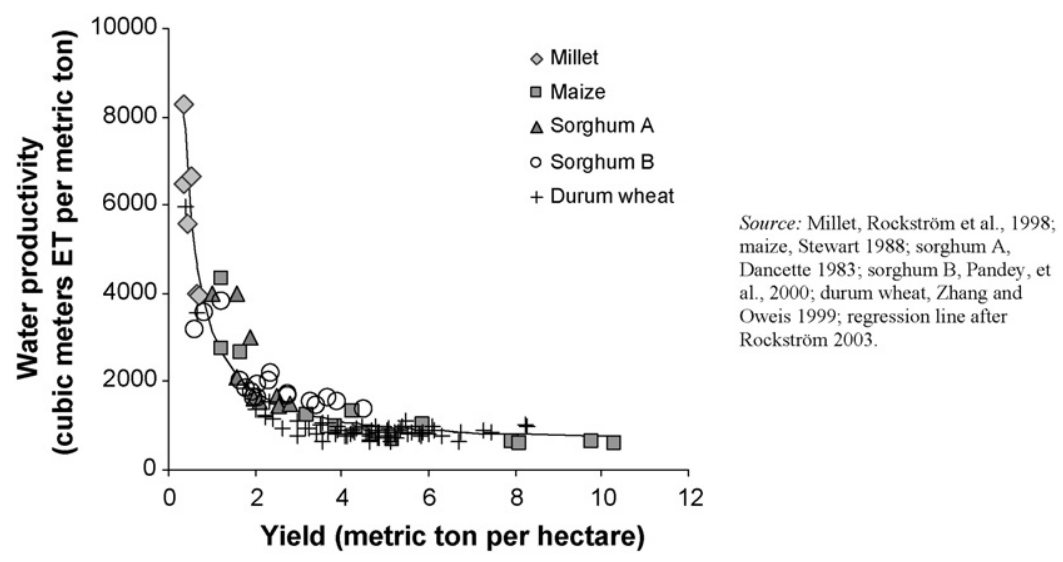

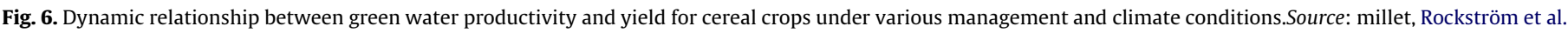

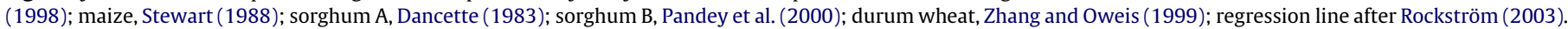


area under cultivation might thus increase runoff, depending on the original land use. The downstream impacts of large-scale water harvesting efforts and land use change are highly site specific. Basin-scale hydrological research is needed to enhance understanding of the impacts.

Water plays a critical role in sustaining both aquatic and terrestrial ecosystem services (Falkenmark et al., 2007) and maintaining their resilience to cope with shocks, such as extreme droughts or floods (Folke et al., 2002). Maintaining ecosystem services in an agricultural landscape can be helpful in managing water resources. For example, sustaining a high spatial configuration of different land use types (e.g., forests, grasslands, wetlands, cropland) can conserve green and blue water resources, improve the release rate of blue water, and increase the sources of income. This is particularly relevant for rainfed systems under a changing climate with more frequent shocks. Trends during the past 50 years indicate that expanding agricultural land has been the major cause of degradation of ecosystem services (MA, 2005). Meeting the Millennium Development Goals on hunger might require that agricultural land expands by $0.7 \%$ per year (Rockström et al., 2007), putting further pressure on ecosystems.

\section{Towards a paradigm shift to water management in rainfed agriculture}

Despite the numerous opportunities for upgrading rainfed agriculture through new water management investments to reduce yield gaps and enhance water productivity, efforts in this area have so far largely been lacking. Needed now are new water management policies and investments in human capacities, research, institutional development, and specific technologies.

New policies should be based on an ecohydrological perspective in which rainfall is regarded as the freshwater resource (Falkenmark and Rockström, 2004). However, the focus of Integrated Water Resource Management (IWRM) remains on planning, allocating and managing blue water resources for irrigation, industry, and water supply, while recognizing the need to safeguard environmental water flows for aquatic ecosystem functions in rivers, lakes, wetlands, and estuaries. Yet key ecosystem services, such as agricultural production, depend on green water in terrestrial ecosystems. Hence green and blue water resources should be planned and managed together, forming a new, widened approach to IWRM.

In such a paradigm shift, water harvested at the local scale for crop production will be recognized as a productive water use. Thus, water resource governance and management encompass both the local (catchment) scale, which is relevant to most rainfed agricultural systems, and the larger basin scale, in a nested approach.

One implication of the evidence and arguments in this paper is that a new approach to IWRM should focus more closely on downscaling water resource management from the river basin to the catchment scale (generally below $1000 \mathrm{~km}^{2}$ ). An integrated analysis of water resources across scales may illustrate interesting win-win opportunities between upstream green water investments (such as water harvesting) and implications for downstream water uses (such as reduced sedimentation).

In rainfed agriculture, emphasis must be on securing water to bridge dry spells and to increase agricultural and water productivity through new technological water management options, facilitated through institutional and policy interventions. This must be done without decreasing resilience in agricultural landscapes.

A natural consequence of a re-orientation of water resource management, starting from rainfall as the freshwater resource, is to abandon the current (artificial) divide between irrigated and rainfed agriculture. Irrigated agricultural systems generally depend, in part, on contributions from green water. Conversely, the most promising avenue to upgrade rainfed agriculture in regions with water constraints is to invest in blue water management options, such as supplemental irrigation. Breaking this governance divide will be an important strategic step toward raising the institutional priority regarding investments in rainfed agriculture. It will also provide a larger set of management alternatives, ranging from fully rainfed to fully irrigated systems.

Also needed are investments in local institutions, such as farmers' organizations and small-scale credit schemes, which are particularly important in this context, as many farm households cannot afford the initial costs required for small-scale water harvesting (Fox et al., 2005). Public investments in infrastructure such as roads are crucial so that farm produce can be transported easily to markets. Furthermore, private investors must be attracted to investments in rainfed agriculture. Investments are needed also in capacity building, as the lack of knowledge on farms and among extension service personnel regarding water harvesting and conservation agriculture can limit yields in rainfed areas (Rockström et al., 2009a), engendering development initiatives are needed, as women play major roles in agriculture, particularly in rainfed areas. Finally, investments in strategic research are needed to bridge the gap between achievable and potential yields.

\section{Conclusions}

The Comprehensive Assessment of Water Management in Agriculture highlights the urgent need for new water management investments in agriculture to meet future food demands, in light of increasing pressure on water resources and uncertainty due to climate change. Rainfed agriculture will continue to play a dominant role in providing food and generating livelihoods, particularly in poor countries. The global hotspots in terms of water, food and livelihoods are in the dryland regions; i.e., the savannah and steppe regions. Policy goals in those areas must include: (1) doubling agricultural productivity with existing water resources; (2) improving knowledge and implementing affordable strategies to achieve potential levels of land and water productivity; and (3) conducting more research on the potential cascading effects on watershed and basin scales, due to large-scale adoption of agricultural water technologies.

Upgrading rainfed agriculture in the world's water hotspots during the next 50 years will require the same level of concerted water governance and management priorities given to irrigated agriculture during the previous 50 years. This will include efforts involving institutional capacities, policy frameworks, knowledge generation, and finance. The current lack of governance, management, and investment priorities given to upgrading rainfed agriculture in developing countries often is justified by the "marginal" potential in rainfed areas and the major water scarcity problems in "dryland" areas. However, water constraints are not always related to absolute water shortage, but rather to the variability of supply. Water management to bridge dry spells can greatly reduce risks. Low yields and low water productivity due to large, non-productive water flows offer windows of opportunity, which can be realized by implementing a new approach to IWRM that encompasses both green and blue water resources from the catchment to basin scale.

\section{References}

Agarwal, A., 2000. Drought? Try capturing the rain. Briefing Paper. Centre for Science and Environment, New Delhi.

Barron, J., Rockström, J., Gichuki, F., Hatibu, N., 2003. Dry spell analysis and maize yields for two semi-arid locations in East Africa. Agricultural and Forest Meteorology 117 (1-2), 23-37. 
Bewket, W., Sterk, G., 2005. Dynamics in land cover and its effects on stream flow in the Chemoga watershed, Blue Nile, Ethiopia. Hydrological Processes 19, 445458 .

Calder, I.R., 1999. The Blue Revolution: Land Use and Integrated Water Resources Management. Earthscan, London.

Comprehensive Assessment of Water Management in Agriculture, 2007. In: Molden, D. (Ed.), Water for Food, Water for Life. A Comprehensive Assessment of Water Management in Agriculture. International Water Management Institute (IWMI). Earthscan, London, UK.

Conway, G., Toenniessen, G., 1999. Feeding the world in the 21 st century. Nature 402, 55-58.

Dancette, C., 1983. Estimation des besoins en eau des principales cultures pluviales en zone soudano-sahélienne. L'Agronomie Tropicale 38 (4), 281-294.

de Fraiture, C., Wichelns, D., Rockström, J., Kemp-Benedict, E., Eriyagama, N., Gordon, L.J., Hanjra, M.A., Hoogeveen, J., Huber-Lee, A., Karlberg, L., 2007. Looking Ahead to 2050: Scenarios of alternative investment approaches. In: Molden, D. (Ed.), Water for Food, Water for Life: A Comprehensive Assessment of Water Management in Agriculture. Comprehensive Assessment of Water Management in Agriculture. Earthscan, and Colombo: International Water Management Institute, London, pp. 91-145.

Derpsch, R., 1998. Historical review of no-tillage cultivation of crops. In: Benites, J., Chuma, E., Fowler, R., Kienzle, J., Molapong, K., Manu, J., Nyagumbo, I., Steiner, K., van Veenhuizen, R. (Eds.), Conservation Tillage for Sustainable Agriculture. Proceedings from an International Workshop, Harare, 22-27 June. Part II (Annexes). Deutsche Gesellschaft fur Technische Zusammenarbeit, Eschborn, Germany.

Derpsch, R., 2005. The extent of conservation agriculture adoption worldwide: implications and impact. Keynote Paper at the 3rd World Congress on Conservation Agriculture, Regional Land Management Unit, World Agroforestry Centre, 3-7 October, Nairobi.

Doorenbos, J., Pruitt, W.O., 1992. Crop Water Requirements. FAO Irrigation and Drainage Paper. Food and Agriculture Organization, Rome.

Evenari, M., Shanan, L., Tadmor, N.H., 1971. The Negev: The Challenge of a Desert. Harvard University Press, Cambridge, Mass.

Falkenmark, M., 1986. Fresh water-time for a modified approach. Ambio 15 (4), 192-200.

Falkenmark, M., Rockström, J., 2004. Balancing Water for Humans and Nature: The New Approach in Ecohydrology. Earthscan, London.

Falkenmark, M., Finlayson, C.M., Gordon, L.J., et al., 2007. Agriculture, water and ecosystems: avoiding the costs of going too far. In: Molden, D. (Ed.), Water fo Food, Water for Life. A Comprehensive Assessment of Water Management in Agriculture. International Water Management Institute (IWMI). Earthscan, London, UK.

Fan, S., Hazell, P., Haque, P., 2000. Targeting public investments by agro-ecological zone to achieve growth and poverty alleviation goals in rural India. Food Policy 25 (4), 411-428

FAOSTAT, 2005. Database. Food and Agriculture Organization, Rome. http://faostat.fao.org/ (accessed November 2005)

Folke, C., Carpenter, S., Elmqvist, T., Gunderson, L., Holling, C.S., Walker, B. Bengtsson, J., Berkes, F., Colding, J., Danell, K., Falkenmark, M., Gordon, L. Kasperson, R., Kautsky, N., Kinzig, A., Levin, S., Maeler, K.-G., Moberg, F., Ohlsson, L., Olsson, P., Ostrom, E., Reid, W., Rockström, J., Savenije, H., Svedin, U., 2002. Resilience and Sustainable Development: Building Adaptive Capacity in a World of Transformations. ICSU Series on Science for Sustainable Development No. 3. ICSU, Paris, France, p. 37.

Fox, P., Rockström, J., Barron, J., 2005. Risk analysis and economic viability of water harvesting for supplemental irrigation in semi-arid Burkina Faso and Kenya. Agricultural Systems 83 (3), 231-250.

Gerten, D., Hoff, H., Bondeau, A., Lucht, W., Smith, P., Zaehle, S., 2005. Contemporary "green" water flows: simulations with a dynamic global vegetation and water balance model. Physics and Chemistry of the Earth 30, 334-338.

Hatibu, N., Lazaro, E.A., Mahoo, H.F., Rwehumbiza, F.B., Bakari, A.M., 1999. Soil and water conservation in semi-arid areas of Tanzania: national policies and local practices. Tanzania Journal of Agricultural Sciences 2 (2), 151-170.

Hatibu, N., Young, M.D.B., Gowing, J.W., Mahoo, H.F., Mzirai, O.B., 2003. Developing improved dryland cropping systems for maize in semi-arid Tanzania. Part 1: Experimental evidence of the benefits of rainwater harvesting. Journal of Experimental Agriculture 39 (3), 279-292.

Hobbs, P.R., Gupta, R.K., 2002. Rice-wheat cropping systems in the Indo-Gangetic plains: issues of water productivity in relation to new resource conserving technologies. In: Kijne, J.W. (Ed.), Water Productivity in Agriculture: Limits and Opportunities for Improvement. CABI Publishing, Wallingford, UK.

Government of India, 2005. Serving Farmers and Saving Farming - 2006: A Year of Agricultural Renewal. Third Report. New Delhi, Ministry of Agriculture National Commission on Farmers. India.

IPCC (Intergovernmental Panel on Climate Change), 2007. Climate Change 2007. Fourth Assessment Report. Cambridge University Press, Cambridge, UK.

Irz, X., Roe, T., 2000. Can the world feed itself? Some insights from growth theory. Agrekon 39 (3), 513-528.

Jewitt, G.P.W., Garrat, J.A., Calder, I.R., Fuller, L., 2004. Water resources planning and modelling tools for the assessment of land use change in the Luvuvhu Catchment, South Africa. Physics and Chemistry of the Earth 29, 1233-1241.

Klaij, M.C., Vachaud, G., 1992. Seasonal water balance of a sandy soil in Niger cropped with pearl millet, based on profile moisture measurements. Agricultural Water Management 21 (4), 313-330.
Landers, J.N., Mattana Saturnio, H., de Freitas, P.L., Trecenti, R., 2001. Experiences with farmer clubs in dissemination of zero tillage in tropical Brazil. In: GarcíaTorres, L., Benites, J., Martínez-Vilela, A. (Eds.), Conservation Agriculture, A Worldwide Challenge. Food and Agriculture Organization, Rome.

MA, 2005. Millennium ecosystem assessment, ecosystems and human well-being: current status and trends. In: Hassan, R., Scholes, R., Ash, N. (Eds.), Fresh water, vol. 1. Isaland Press, Washington/London/Covelo. , Chapter 7In: http://www. millenniumassessment.org/en/Products.Global.Condition.aspx.

Molden, D.J., Sakthivadivel, R., Keller, J., 2001. Hydronomic Zones for Developing Basin Water Conservation Strategies. Research Report 56, International Water Management Institute (IWMI), Colombo, $30 \mathrm{pp}$.

Molle, F., 2003. Development Trajectories of River Basins-A Conceptual Framework. Research Report 72, International Water Management Institute (IWMI), Colombo, $31 \mathrm{pp}$.

Molle, F., Wester, P., Hirsch, P., Jensen, J.R., Murray-Rust, H., Paranjpye, S., Zaag, P. van der, 2007. River basin development and management. In: Molden, D. (Ed.), Water for Food Water for Life: A Comprehensive Assessment of Water Management in Agriculture. Earthscan, London, pp. 585-625

Oweis, T., 1997. Supplemental Irrigation: A Highly Efficient Water-use Practice. International Center for Agricultural Research in the Dry Areas, Aleppo, Syria.

Oweis, T., Hachum, A., 2001. Reducing peak supplemental irrigation demand by extending sowing dates. Agricultural Water Management 50 (2), 109-123.

Pandey, R.K., Maranville, J.W., Admou, A., 2000. Deficit irrigation and nitrogen effects on maize in a Sahelian environment. I: Grain yield and yield components. Agricultural Water Management 46 (1), 1-13.

Rockström, J., 2003. Water for food and nature in drought-prone tropics: vapour shift in rain-fed agriculture. Royal Society Transactions B: Biological Sciences 358 (1440), 1997-2009.

Rockström, J. Falkenmark, M., 2000. Semiarid crop production from a hydrological perspective: gap between potential and actual yields. Critical Reviews in Plant Science 19 (4), 319-346.

Rockström, J., Jansson, P.-E., Barron, J., 1998. Seasonal rainfall partitioning under runon and runoff conditions on sandy soil in Niger. On-farm measurements and water balance modelling. Journal of Hydrology 210 (1-4), 68-92.

Rockström, J., Falkenmark, M., Lannerstad, M., 2007. Assessing the water challenge of a new green revolution in developing countries. Proceedings of the National Academy of Sciences of the United States of America 104 (15), $6253-6260$

Rockström, J., Kaumbutho, P., Mwalley, J., Nzabi, A.W., Temesgen, M., Mawenya, L. Barron, J., Damgaard-Larsen, S., 2009a. Conservation farming strategies in East and Southern Africa: a regional synthesis of crop and water productivity from on-farm action research. Soil and Tillage Research 103, 23-32.

Rockström, J., Falkenmark, M., Karlberg, L., Hoff, H., Rost, S., Gerten, D., 2009b. Future water availability for global food production: the potential of green water to build resilience to global change. Water Resources Research 44, doi:10.1029/ 2007WR006767.

Rosegrant, M., Ximing, C., Cline, S., Nakagawa, N., 2002. The Role of Rainfed Agriculture in the Future of Global Food Production. EPTD Discussion Paper 90. International Food Policy Research Institute (IFPRI), Environment and Production Technology Division, Washington, DC. http://www.ifpri.org/divs/ eptd/dp/papers/eptdp90.pdf

Schreider, S.Yu., Jakeman, A.J., Letcher, R.A., Nathan, R.J., Neal, B.P., Beavis, S.G., 2002. Detecting changes in streamflow response to changes in non-climatic catchment conditions: farm dam development in the Murray-Darling basin, Australia. Journal of Hydrology 262 (1-4), 84-98.

Seckler, D., Amarasinghe, U., 2004. Major problems in the global water-food nexus. In: Scanes, C., Miranowski, J. (Eds.), Perspectives in World Food and Agriculture 2004. Iowa State Press, Ames, Iowa.

SEI (Stockholm Environment Institute), 2005. Sustainable Pathways to Attain the Millennium Development Goals-Assessing the Role of Water, Energy and Sanitation. Document prepared for the UN World Summit, 14 September, New York. Stockholm.

Siegert, K., 1994. Introduction to water harvesting: some basic principles for planning, design and monitoring. In: Water Harvesting for Improved Agricultural Production. Proceedings of the FAO Expert Consultation, 21-25 November 1993, Cairo. Water Report 3. Food and Agriculture Organization, Rome.

Sreedevi, T.K., Shiferaw, B., Wani, S.P., 2004. Adarsha Watershed in Kothapally: Understanding the Drivers of Higher Impact. Global Theme on Agroecosystems Report 10. International Crops Research Institute for the Semi-Arid Tropics (ICRISAT), Andhra Pradesh, India.

Sreedevi, T.K., Wani, S.P., Sudi, R., Mahesh, S., Patel, J.T., Singh, S.N., Tushar, S., 2006. On-site and Off-site Impact of Watershed Development: A Case Study of Rajasamadhiyala, Gujarat, India. Global Theme on Agroecosystems, Report no. 20. International Crops Research Institute for the Semi-Arid Tropics (ICRISAT), Patancheru, 48 pp.

Stewart, J.I., 1988. Response Farming in Rainfed Agriculture. The WHARF Foundation Press, Davis, Calif.

Stoorvogel, J.J., Smaling, E.M.A., 1990. Assessment of Soil Nutrient Depletion in SubSaharan Africa: 1983-2000, vol. 1, Main Report. Report 28. Winand Staring Centre, Wageningen, Netherlands.

Tanzania Ministry of Agriculture, Food Security, 2003. Study on Irrigation Master Plan. Tanzania Ministry of Agriculture and Food Security (MAFS), Dar es Salaam, Tanzania. 
UN Millennium Project, 2005. Halving Hunger: It Can Be Done. Summary version of the report of the Task Force on Hunger. The Earth Institute at Columbia University, New York, USA.

UNStat, 2005. United Nations Statistics Division, Statistical databases. http:// unstats.un.org/unsd/default.htm (accessed December 2005).

Wani, S.P., Pathak, P., Jangawad, L.S., Eswaran, H., Singh, P., 2003a. Improved management of vertisols in the semiarid tropics for increased productivity and soil carbon sequestration. Soil Use and Management 19 (3), 217222.

Wani, S.P., Pathak, P., Sreedevi, T.K., Singh, H.P., Singh, P., 2003b. Efficient management of rainwater for increased crop productivity and groundwater recharge in Asia. In: Kijne, J.W., Barker, R., Molden, D. (Eds.), Water Productivity in
Agriculture: Limits and Opportunities for Improvement. CABI Publishing and International Water Management Institute, Wallingford, UK, and Colombo.

World Bank, 2000. Spurring Agricultural and Rural Development. In: Can Africa Claim the 21st Century? Washington, DC

World Bank, 2005. Agricultural Growth for the Poor: An Agenda for Development. World Bank, Washington, DC.

Zhang, H., Oweis, T., 1999. Water-yield relations and optimal irrigation scheduling of wheat in the Mediterranean region. Agricultural Water Management 38 (3) 195-211.

Zhang, X., Zwiers, F.W., Hegerl, G.C., Lambert, F.H., Gillett, N.P., Solomon, S., Stott, P.A., Nozawa, T., 2007. Detection of human influence on twentieth-century precipitation trends. Nature 448, 461-466. 